\title{
PENYULUHAN MENGEMBANGKAN PRIBADI REMAJA YANG BERPRESTASI DAN BERDAYA SAING
}

\author{
${ }^{1}$ Fitra Jaya, ${ }^{2}$ Hastono, ${ }^{3}$ Sutrisno \\ ${ }^{1}$ Dosen Fakultas Keguruan dan Ilmu Pendidikan. \\ ${ }^{2,3}$ Dosen Fakultas Ekonomi Universitas Pamulang \\ Email : ${ }^{1}$ fitrajaya1993@gmail.com
}

\begin{abstract}
ABSTRAK
Tujuan yang ingin dicapai dalam kegiatan ini adalah untuk mengetahui sejauh mana keberhasilan penyuluhan mengembangkan pribadi remaja untuk bisa berprestasi dan dapat bersaing di masa yang akan datang, Pengabdian Masyarakat di Yayasan Al Badar. Jumlah peserta penyuluhan kurang lebih 30 orang.

Metode pelaksanaan kegiatan dengan cara menggunakan teknik semiar, pemaparan secara langsung di ikuti oleh diskusi dan diakhiri dengan evaluasi.

Dengan ada nya kegiatan ini menjadikan para peserta dapat meraih prestasi dan mempuyai daya saing yang tinggi. Remaja adalah generasi emas pembawa masa depan bangsa. Segala potensi dan kemampuan harus diarahkan agar bisa menjadi pelajar yang berahlak dan prestasi. Kerja sama orang tua, guru dan sekolah juga sangat berperan dalam perwujudan hal tersebut agar dapat menjadikan siswa yang dapat berjasa menciptakan karya-karya besar untuk Agama, bangsa dan negara
\end{abstract}

\section{Kata Kunci : Pengembangan Diri, Prestasi, Berdaya Saing}

\section{PENDAHULUAN}

SMP Swasta Al Badar ILS Pamulang terletak di wilayah Propinsi Banten,tepatnya di kelurahan Pamulang Barat Kecamatan Pamulang Kota Tangerang Selatan. Adapun letak sekolah berada di wilayah komplek Pamulang Permai Barat bersebelahan dengan SMPN 4 Pamulang dan SMPN 17 Pamulang, serta merupakan wilayah yang berdekatan dengan ibu kota Jakarta. SMP Al Badar ILS berada di lingkungan pendidikan mulai dari tingkat TK, SD, SMP, SMA sampai dengan Perguruan Tinggi, hal tersebut memotivasi terjadinya persaingan di dunia pendidikan yang cukup ketat. Para siswa dari berbagai sekolah dasar yang masuk SMP Swasta Al Badar ILS sebagian besar menetap di wilayah pamulang, pondok benda dan sekitarnya. Dengan banyak lembaga pendidikan sekolah dasar yang ada merupakan asset yang amat berpengaruh pada perkembangan Smp Swasta Al Badar, selain itu letak SMP Al Badar ILS yang berada dengan Kecamatan Pamulang yang memudahkan akses siswa/i untuk menuju ke sekolah ini.

Gedung SMP Al Badar ILS berada didalam wilayah perumahan komplek pamulang permai yang jauh dari keramaian jalan raya dan umum, keadaan tersebut 
sangat baik untuk siswa dalam melaksanakan kegiatan belajar mengajar yang kondusif dan nyaman, serta terjaganya keamanan dari lingkungan setempat.

Letak SMP Al Badar ILS yang berada diantara dua SMP Negeri memberikan keuntungan tersendiri dalam pemenuhan Peserta didik baru,di mana para peserta didik yang tidak diterima di SMP Negeri dapat diterima di SMP Al Badar ILS.

Berdasarkan latar belakang yang dipaparkan di atas maka identifikasi masalah adalah para remaja kurang memahami bagaimana cara mengembangkan diri untuk berprestasi dan dapat bersaing di masa yang akan datang. Sasaran dari program Pengabdian Masyarakat yang akan kami lakukan ini adalah para pelajar Yayasan Al Badar. Jumlah peserta penyuluhan kurang lebih 30 orang.

\section{METODE PELAKSANAAN KEGIATAN}

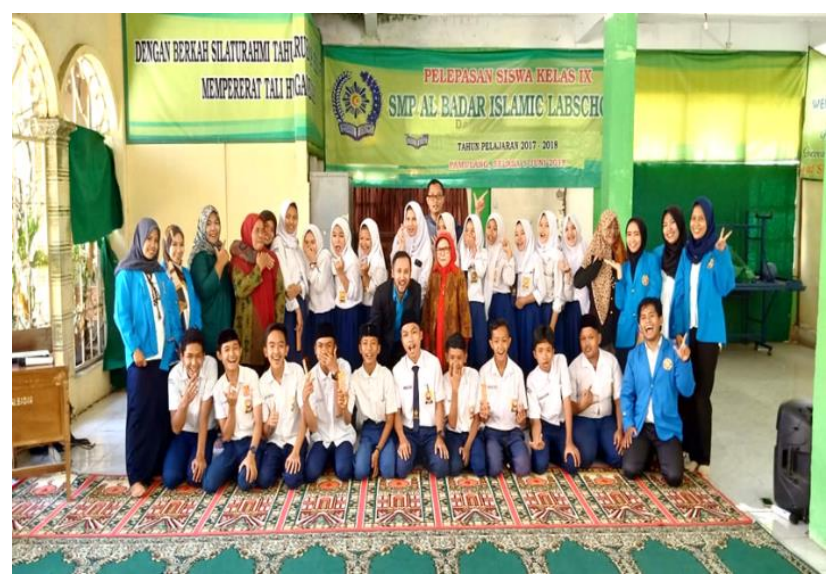

Metode pelaksanaan
kegiatan dengan cara menggunakan teknik semiar, pemaparan secara langsung di ikuti oleh diskusi dan diakhiri dengan evaluasi.

\section{HASIL DAN PEMBAHASAN}

Pelajar idaman adalah pelajar yang hatinya selalu terkait dengan Allah SWT. Dia selalu berusaha menjalankan segala perintah dan menjauhi laragan-Nya. Dalam kehidupan sehari-hari, ia selalu mencerminkan perilaku yang baik terhadap orang tua, guru, keluarga, lingkungan dan masyarakat. Prestasi dan kontribusinya dalam menebar kebaikan selalu dirindukan oleh banyak orang. Sebagaimana islam memandang pendidikan, perhatian utuh terhadap anak harus diberikan orang tua sejak usia balita hingga remaja agar proses perkembangan anak dapat berjalan dengan baik sesuai harapan.

Di era globalisasi, menjadi pelajar berakhlak bukanlah hal yang mudah, banyak penghalang yang dapat membawa mereka terjerumus ke jurang kegelapan. Pelajar sebagai generasi penerus bangsa memiliki kedudukan atau peranan yang sangat penting. Tetapi, kehidupan pelajar saat ini sangat jauh dari apa yang kita harapkan. Hal ini tampak dari aktifitas yang mereka lakukan baik di lingkungan keluarga, sekolah, kampus, maupun masyarakat umum. Beberapa fenomena mengejutkan telah beredar di masyarakat saat ini. Diantaranya: tawuran, pemerasan, kekerasan hingga pembunuhan. Hal ini dikarenakan rendahnya pendidikan akhlak di kalangan pelajar sehingga dapat berdampak pada perilaku dan menurunnya prestasi pelajar disekolah.

Realita buruk yang menimpa para pelajar harusnya mampu meningkatkan kesadaran kita untuk menciptakan generasi pelajar yang mempunyai akhlaqul karimah dan mampu meraih prestasi di berbagai bidang agar dapat bermanfaat bagi 
agama, bangsa dan negara. Dalam usaha mewujudkan hal itu, kita harus mengetahui: faktor penyebab turunnya akhlak pelajar yang berdampak pada prestasi, serta apa yang seharusnya kita lakukan untuk menciptakan pelajar sebagai generasi muda yang berakhlaq dan berprestasi.

Remaja merupakan seorang anak yang sedang mengalami masa transisi dari masa anak-anak menuju dewasa. Mereka adalah cikal bakal generasi yang akan datang sebagai harapan dan cita-cita bangsa. Mereka hadir sebagai tiang penyangga dalam masyarakat yang memiliki kemampuan dan efektivitas dalam beraktivitas.

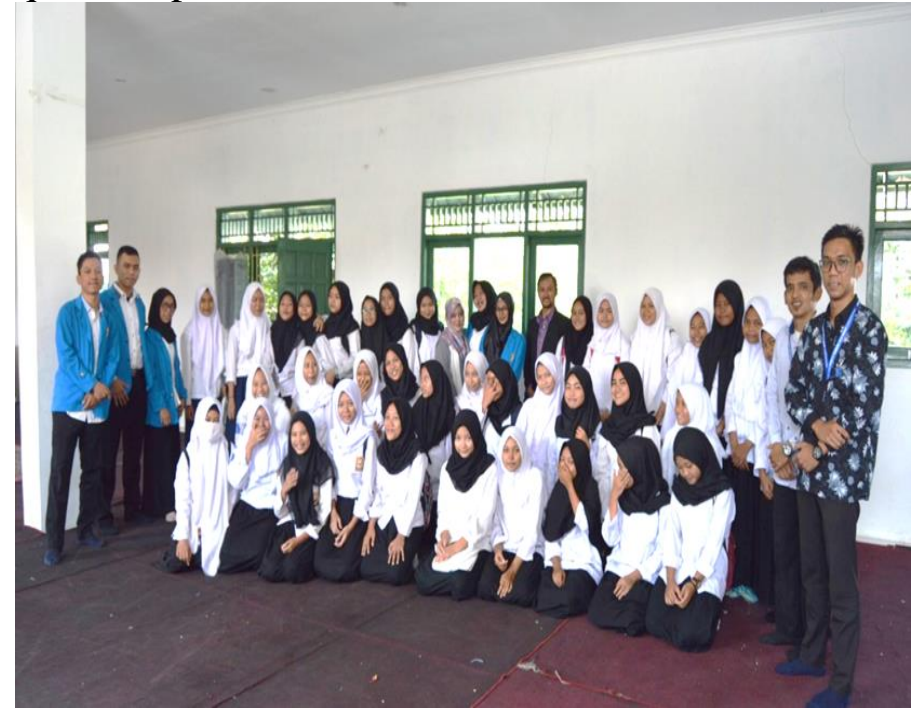

\section{KESIMPULAN DAN SARAN}

Dengan ada nya kegiatan ini menjadikan para peserta dapat meraih prestasi dan mempuyai daya saing yang tinggi. Selama kegiatan berlangsung peserta memberikan tanggapan yang baik, hal ini dapat dilihat dari dukungan mereka dalam setiap kegiatan yang di adakan, sehingga dapat membantu para peserta dalam mempersiapkan masa depannya. Remaja adalah generasi emas pembawa masa depan bangsa. Segala potensi dan kemampuan harus diarahkan agar bisa menjadi pelajar yang berahlak dan prestasi. Kerja sama orang tua, guru dan sekolah juga sangat berperan dalam perwujudan hal tersebut agar dapat menjadikan siswa yang dapat berjasa menciptakan karya-karya besar untuk Agama, bangsa dan negara

\section{DAFTAR PUSTAKA}

https://www.kompasiana.com/an/5719c1f41a7b61dc05c50cd9/psikologi-remaja-

karakteristik-dan-permasalahannya?page $=2$

ruangkonselingwatuna.blogspot.com/2012/02/remaja-berprestasi.html http://bakhrisyaifu199.blogspot.com/2014/11/menciptakan-pelajar-berakhlakyang.html

Sunarsi, D., \& Asmalah, L. (2018). Pelatihan Manajemen Pengembangan Diri Bagi Penerima Beasiswa RZIS UGM Dan Dompet Shalahuddin Jogjakarta. Jurnal Pengabdian Dharma Laksana, 1(1). 